Ankara Üniversitesi

SBF Dergisi,

Cilt 68, No. 1, 2013, s. 1 - 20

\title{
AN ETHNOGRAPHIC VIEW ON AFRICAN FOOTBALL MIGRANTS IN ISTANBUL
}

\author{
Martin Büidel
}

M. A. Student, University of Bayreuth

\begin{abstract}
Research on African migration to Turkey has so far neglected further inquiry into the presence of footballers from West African countries in İstanbul. Present approaches to football migration tend to victimize 'stranded' migrants and in migration research in general, various migration pathways are put into fixed categorizations, losing sight of their diversity. Based on ethnographic research with a group of African football players, I argue that there is a need to shift the view on African migrations in the context of international football. The different migration biographies and everyday experiences of football players in İstanbul presented in this article show a nuanced picture of migration phenomena within global football. Acknowledging the football players as actors in their own right and looking at their practices and rhetoric with regard to their ambitions in football is a necessary step toward overcome too narrow categorizations and allows a better understanding of their migrations.
\end{abstract}

Keywords: African migration, football, İstanbul, migration biographies, ambitious football players

\section{İstanbul'daki Afrikalı Futbol Göçmenleri Üzerine Etnografik Bir} Inceleme

\section{Özet}

Türkiye'deki Afrikalı göçmenler konusunda yapılan araştırmalar genellikle Batı Afrika'dan gelen futbolcuları inceleme konusu pek yapmamışlardır. Fubolcu olmak amacıyla yapılan göçlere genellikle başarısız olmuş göçler gözüyle bakılmakta ve göçmenler kurbanlaştırılmaktadır. Genel göç çalışmalarındaki eğilim de farklı göç yol ve yöntemlerini içindeki çeşitliliği görmeden standartlaştırma eğilimindedir. Bu çalışma kapsamında, Türkiye'deki etnografik araştırmalarıma dayanarak, futbolcu olma saikiyle göç eden Afrikalılara dair bu yaklaşımın değiştirilmesi gerektiğini öne sürmekteyim. Yaptığım görüşmeler sonucu edinilen hikaylerden anlaşılmakta ki göçmenlerin günlük hayatına dair pratiklerdeki farklılıklar, futbolcu olma saikiyle yapılan göçlerin tüm göç kategorileri içinde yeniden yorumlanması ihtiyacını doğurmaktadır.

Anahtar Sözcükler: Afrika göçü, futbol, İstanbul, göç biyografileri, hırslı futbolcular 
2 - Ankara Üniversitesi SBF Dergisi • 68-1

\section{An Ethnographic View on African Football Migrants in İstanbul 1}

'Everybody has his own ambitions'

\section{Introduction}

In early June 2012, Martins, a young Nigerian, called me almost one year after I had met him during my fieldwork in İstanbul. He told me that resident permit regulations in Turkey had been relaxed as of the beginning of the month. His information was supported by a press report that I found on the internet, stating that a decree from the Ministry of the Interior would not only ease the procedure to obtain a work permit, but will also provide a chance for irregular foreigners to be legalized against a penalty payment issued for visa overstays (Today's Zaman, 2012). As Martins, who came to Turkey to find employment as a professional football player, did overstay his visa after not being able to sign up with a club, his hope was to now acquire legal status for his current stay in İstanbul, in order to be able to travel on to his desired destination in Germany. Similarly, many of the football players whom I worked with about a year earlier were now looking forward to improving their often precarious situation: Finally obtaining a residence permit would provide a chance to be signed by one of the lower-league clubs in Turkey, and eventually create the possibility to legally travel on to a desired destination in the European Union (EU).

${ }^{1}$ I presented an earlier version of this paper at the workshop 'African migrants in İstanbul', held at Galatasaray University, 23.09.2011, in accord with an invitation by Didem Danış of the sociology department.

${ }^{2}$ Emmanuel. Personal Interview, 08.09.2011. 
These changes in residency regulations and the hopes of the migrants connected to this new policy allow for a revealing insight into the case of African football players in Turkey. In the summer of 2011, I did ethnographic research in İstanbul with a group of undocumented migrants from Nigeria and Ghana. ${ }^{3}$ Being aware of the presence of football players from various West African countries in the city, I was interested in to which extent football might be a motive and a vehicle for their individual migration projects. İstanbul has become an important hub for diverse migrations from Africa and the football economy of Turkey is closely connected to the major leagues in European Union countries. Thus, many African players try to find a way into European football via Turkey, as it could prove to be the stepping stone for their further careers. Nevertheless, current literature on football migration to Europe seems to identify only two, obviously quite extreme possibilities for migrating footballers from the African continent: making it to the high-profiled professional leagues and getting a well-paid job at one of the clubs there, or, on the other hand, getting stranded in Europe or on its periphery, abused by unscrupulous agents and club managers and dumped into illegality and hopelessness.

However, as I realized during my fieldwork, the diverse biographies of football migrants in İstanbul and their ongoing struggle to establish themselves in football show a nuanced picture of migration phenomena in the global football economy. It further accounts that migration movements in football are not a distinct phenomenon but must be seen within the wider context of African migrations to Turkey in general. In fact, they are very much part of similar motivations and means of African migration flows in general. Therefore, I argue, there is an urgent need to broaden the discussion with regard to migration from Africa in international football. For this, I draw from observations and informal conversations that I conducted at a training ground in Feriköy, not very far from the central Taksim square and during different other encounters with some of the football players in İstanbul. In addition, several unstructured interviews inform my empirical material.

In order to contextualize my own findings within the situation of African migrants in İstanbul more generally and also within the context of migrations in

${ }^{3}$ I owe thanks to Claudia Liebelt at the chair of Social Anthropology/University of Bayreuth, who introduced me to the research idea in the first place and is supervising my work. Further I acknowledge support from Erdmute Alber and Christian Ungruhe (both at the chair of Social Anthropology/University of Bayreuth) for the sharing of ideas and also the Heinrich Böll Stiftung e.V. for providing support in form of a scholarship. 
international football, I will first address some aspects of the framework of the international football economy which are relevant for the individual migration projects. I will also illustrate some everyday life issues of African migrants in Turkey. Then I shall turn to my own research, highlighting the phenomenon of ambitious football players from West African countries, trying to find a way into European professional football. Beside some ethnographic insights into the regular training and the football pitch in Feriköy as a meeting point for the migrants, I will draw on stories of three football players, Simon, Martins and Andrew, who found a way in-between and manage to keep their vision of playing professional football alive. I will show that while they stand outside the focus of football migration research, they should be considered in a comprehensive account of these migrations, as they are part of the international football economy as well. Conceptually, I plead for moving beyond fixed categorizations of football migrants or others. Rather, I argue for looking at the practices and rhetoric of the migrants themselves, as they understand how to use frames like the football economy in order to progress in their individual migration projects.

\section{African migrations in the global football economy}

The number of African footballers playing in European professional football leagues has been growing fast since the mid-1990s. This is partly due to new regulations in the most important football associations that relaxed the restrictions in reference to the number of foreign players in a line-up and finally got rid of them altogether. And anyway, football has been the most prominent sport in many African countries ever since it was introduced in colonial times (Alegi, 2010: 1). Having had remarkable successes at the most important competitions of world football during the 1990s, African football gained momentum on the global stage and received wider recognition within the international football community. ${ }^{4}$ For the economically powerful European clubs it became more and more interesting to sign players from successful African national teams or to look for upcoming talents in the most promising countries. Today, a wide network of talent recruitment exists, ranging from institutionalized football academies and youth teams in clubs to sporadic scouting events aimed at finding talented young players (Darby vd.,

\footnotetext{
${ }^{4}$ Cameroon reached the quarter-finals at the World Cup 1990, Nigeria reached the round of the last 16 at the World Cup 1994, see FIFA.com, "Previous FIFA World Cups", http://www.fifa.com/worldcup/archive/ (accessed, 09.07.2012).
} 
2007). Scouts and agents in cooperation with European club managements have been described as main actors in the transfer of African players. ${ }^{5}$

Accordingly, African football migration is predominantly understood as a relocation of the principal place of residency from an African to a European country for the duration of employment at a club. While some players return to their home countries after ending their professional career, others stay in one of the countries they have been playing in. Several scholars use statistical samples of the two major leagues in different European countries for a quantitative analysis of football migrations (Bale, 2006:410). This allows them to trace some of the trajectories of players in professional teams, as well as the transfer networks within which their movements are negotiated. Theoretically they mainly make use of economic terms to describe the trade with players and highlight 'push and pull factors' which further promote the 'exodus of African talent' (Darby, 2010:245). While this provides some insights into the global processes in players' movements within the football economy, the approach makes visible only some parts of a bigger picture, although some even claim to 'explain the presence of African footballers abroad' in general (Poli, 2008:1).

Most attention is thus given almost exclusively to successful professional players, who found a way into well-paid engagement at a European club. Those who fail or who follow paths 'in-between' are neglected or stigmatized as victims of an unscrupulous business. Even in scientific accounts, this aspect is sensationalized, describing cases of teenage footballers who, after being dumped by their agent, 'turned to child prostitution as their only means of survival' (Darby, 2010:253). Victimizing players who fail to be signed up with clubs in Europe implies that there seems to be no alternate ways which migrations related to the football economy can possibly take. The examples of the Nigerian and Ghanaian players in İstanbul, on the other hand, give a very different account and show that there are many ways between the mentioned extremes which are often outside of high-level football. Therefore in Turkey, positioned at the fringes of the EU, quite different cases of migrating football players can be found, who do not fit into the categories of football migrants constructed in common research approaches. Directing attention towards the migrating players themselves will henceforth help reveal their own motivations and make visible the paths that their migrations take. Their ambition to become a professional football player is a possible reality, around which the migrants organize their daily life in İstanbul. Beside regular training sessions and football as a central theme, their everyday struggles resemble much that of

\footnotetext{
${ }^{5}$ On the involvement of scouts, recruiters and agents in player transfers (Poli, 2008: 6),
} on African club officials and involvement in transfers (Pannenborg, 2010) 
African migrants in general. I will therefore relate my own findings to the situation of African migrants in İstanbul, drawing on aspects that were highlighted in the respective literature.

\section{African migrants in İstanbul and the case of football players}

Since some years, Turkey has become an important (transit) destination for migrations from countries of the Global South (İçduygu ve Kirişçi, 2009). Ever since the late 1990s, Turkey, which had been characterised as an emigration country for many decades, 'appeared as a major route of irregular migrations towards Europe' (Danis vd., 2009:462). Today, especially İstanbul is a hot spot of all kinds of migrations, also those that are often categorized as illegal, irregular or that operate in a grey zone of smuggling and human trafficking. African migrations are a relatively small part of irregular migration to and through Turkey when compared with movements from Asian or Middle Eastern countries, such as Afghanistan or Iraq (Danis vd., 2009:462). Migrants often cross İstanbul on their way to Europe or stay in the city for several years due to very diverse reasons. While some West Africans, especially Nigerian citizens who are involved in business, are legal residents in Turkey, many overstay their visa and are thus converted into an irregular residence status. Comparable to other irregular migrant groups in İstanbul, those African migrants live in precarious circumstances, lacking access to basic civil rights or conventional job opportunities. Thus, Didem Danış writes: 'Undocumented migrants are vulnerable groups that are trying to survive in precariousness. In some cases, they are suffering stigmatization and are often perceived as 'illegal' persons. The fact that they do not have the required papers to stay and work in the country creates a constant fear of 'foreigners' (Danis vd., 2009:448).

Beside refugees from authoritarian or war-ridden countries like Eritrea and Somalia, the biggest migrant groups are Nigerians and Ghanaians, who apparently leave their home countries mainly for economic reasons (Brewer ve Yükseker, 2009:680). While they usually enter the country with valid visas and often hope to soon be able to travel on to the EU, many seem to get stuck in İstanbul for longer periods of time (Brewer ve Yükseker, 2011). Once accepting the necessity of organizing acceptable living conditions for their current stay in Turkey, most of the West African migrants can rely on networks based on ethnicity and nationality that have evolved in İstanbul during the last few years (Suter, 2012). Housing and as well as informal work is often found in neighbourhoods like Kumkap1, Tarlabaşı, Kurtuluş or Osmanbey, which according to Brewer and Yükseker are 'attraction points for irregular migrants from various regions' (Brewer ve Yükseker, 2009:692). Especially in order to 
generate income, migrants seek out these places because they offer an array of different opportunities: working in a workshop, the possibility of operating one's own small shop or restaurant, working in the business of fellow nationals. Dependence on their residence and legal status, the access to jobs and monies such as remittances from family or friends -, or support within ethnic or national communities are some of the many factors which produce quite a heterogeneous situation for migrants in İstanbul.

The group of football players that I met during my research in 2011 shares characteristics of these living conditions and everyday problems. While some received a legal residence permit after the marriage with a Turkish citizen, most of them live in the city without valid documents after overstaying their visa. Many of these footballers live in areas like Kurtulus and share the current situation of unemployment with other African migrants, but nevertheless they still follow their ambition to find a way into paid football. Their ways to Turkey are manifold. Some came on invitation of a club in one of the highest divisions of Turkish football but were rejected after a trial period. Others never actually had the chance to show their skills at training sessions of professional teams but organized their trip within networks of football related actors. Often they are brought to Turkey by agents who provide the necessary facilities for the journey against payment by the players themselves. When invited by a club, some can enter Turkey with a three-month sports visa while others use the quite lax visa regulations and get short-time business or tourist visa, usually valid for a few days only. Quite a few footballers, who are not successfully signed up with a professional club within this time frame, return home to continue their football career there. Others make the conscious decision to stay in Turkey, as their journey was paid by family members and friends and many expectations were invested into their attempt to establishing themselves as a professional football player abroad. Somehow, they are now stuck between these expectations, their own ambitions and the dismissal at Turkish professional football. Keeping themselves fit to some extent and organizing their daily life around football related rhetoric and practice also helps keep their dream of still finding a way into professional, or at least paid semi-professional football alive.

\section{Ambitious but Unemployed}

While the body of literature and knowledge on the situation of African migrants in İstanbul has been growing over the last years, the phenomenon of these unemployed football players was neglected so far. Writing about social networks among Nigerian migrants in İstanbul, Brigitte Suter mentions the football player as a category regarding legal, economic and social status. 
Exposed to 'respectless treatment from the Turkish police and authorities', she characterises the experience of football players as similar to 'fellow nationals, many of them searching for possibilities to move on' (Suter, 2012:212). Therefore she sees football players 'in a situation in which the notions of "later" and "in a different place" are omnipresent' (Suter, 2012:212). Although Suter is referring to an ideal type player that is hired by a Turkish club, her observations concerning the feeling of being in transit apply to the situation of unemployed players to some extent as well. Those who still look for a way into the paid professional football business do not see their own future in Turkey. Instead, they perceive an engagement with a Turkish club as a stepping stone for their desired career in Europe. But observations during fieldwork have shown as well that the longer the current stay in Turkey lasts, the less likely a football players is to look for possibilities of moving on to Europe. Some marry in Turkey and settle for a paid contract with one of the many semi-professional clubs in İstanbul. They often still hope to break through and find a professional club to sign them, but their chances decline with every season.

Even if categorizations, such as an ideal type football player or transit migrant, might provide a tool to understand some aspects of the state that migrants find themselves in, they do not really help to describe and understand the migration processes of the football migrants. In categorizing migrants this way, the processual character of individual migrations is lost. In fact, who is actually a football player in a professional sense or 'just' a migrant who sometimes plays football depends on various factors over time. Skills and abilities do not determine success alone. Contacts within networks of football officials and football related actors may often be even more important, and for some, fortune plays a role as well.

Following anthropological approaches to various migration contexts and in regard to football migration, I consider it necessary to shift perspectives towards the social practices of the football players themselves. ${ }^{6}$ In admitting that they play a relevant role in their own migration projects, it will be possible to describe them as acting individuals within complex networks of a global football economy. Their practices and actions in the migration process are

\footnotetext{
6In a volume on 'Migration Theory', anthropologist Caroline Brettell and others highlight that the strength of anthropological approaches to migration is an explicit view on the acting individuals and the structures that surround, shape and influence their actions (Brettell ve Hollifield, 2008:5). While research on football migration so far was emphasizing structural influences and the role of various actors in the transfer of players, I argue for an increased consideration of the role of the football players in their migration projects. They should be considered as actors in their own right, who take part in different decisions during the migration process.
} 
organized around the idea of becoming a professional football player in a yet unknown future. Despite setbacks and failure in the earlier course of their migration projects, they still believe in their own abilities and in further opportunities to successfully enter professional football. Central in relation to this self-confident image is their ambition to use their talent as a footballer in the migration process. While the current situation is difficult and their future in Turkey is uncertain, the notion of being an ambitious football player, who is gifted enough to make it, keeps them focused on pursuing their imagined career.

The analytical term of ambitious football players allows it to describe the daily struggles that these migrants find themselves in, while trying to keep themselves fit at their regular training sessions. Even though as of yet, they may not have achieved their goal of playing in a professional European team, the notion of ambition shows that they are able to keep this vision alive, at least for a certain period of time. This is especially true for their interaction and communication with friends and family in their home countries or abroad who often support them financially. Still, football and the attempt to use their talent as professional players is not the only aspect of everyday life for these migrants. Like many of their fellow nationals they are confronted with the need to organize a living by doing different kinds of jobs. Moreover and besides their regular football training, they are further involved in various activities of migrant communities, such as those organized by churches or national and regional associations. In the following, I address the various aspects of everyday life around the ambition in football, the routine of training, and the manifold pathways in migration biographies in greater detail.

\section{'You just kick the ball': At the training pitch in Feriköy}

While looking for changes in regards to their stagnant football career, many of the players in İstanbul use the opportunity to keep themselves fit at the training pitch of Amatör Lig club Feriköy SK. Three times a week, they gather in the small stadium and share the renting fee among everyone who is able to pay the required 250 Turkish Lira (TL). The group of often fifty or more players is composed of sportsmen from several West and Central African countries, among them Cameroon, Senegal or Liberia and the Democratic Republic of Congo, but mostly Ghana and Nigeria, reflecting the largest national communities of African migrants in İstanbul in general.

\footnotetext{
7 Simon. Personal Interview, 15.09.2011.
} 
For the outsider, the training sessions might at first seem chaotic. Starting at nine in the morning, some players do running exercises, while others trim their muscles or do more technical practice with a ball. Some just talk and wait for the prayer that is always done just before the start of a training match. The match gives some of the players the possibility to practice their skills and routines in match-like situations. As only 22 players are needed for a game, players are exchanged after a certain time period. During almost every training session this is in fact a reason for disputes and reveals ongoing conflicts among some of the players. These conflicts tell a lot about the hierarchies and relationships between individuals and groups of players and they also show that migrants do not in general mutually support each other, but, on the contrary, are often in a state of rivalry, especially with regard to their ambitions in football. A major line of conflict became evident between several elderly players in their thirties, who had stayed in the city for a year or longer, and a heterogeneous group of ambitious younger players in their early twenties, many of whom had arrived in İstanbul quite recently. The latter were often complaining that they were not given enough time during the training matches although they had paid their share of the renting fee for the pitch. Instead, acquaintances of the more veteran players were unfairly granted more time to play. The left out ambitious players stressed that the veteran players had no realistic perspective in professional football anyway, but just played as a leisure activity. Therefore the younger players felt cheated from the opportunity to practice their skills indispensable for their future career in football. A small group of about 15 players even decided to find another location for their training where they would not be dependent on those who determined who was playing and who was not. During the last week of my fieldwork, they started training sessions on a pitch quite close to the one of Feriköy SK, belonging to a Taksim area sporting club. They even found a newly arrived Nigerian coach who supervised some of their technical training. Several players accordingly expressed much more satisfaction with these new training sessions, since they regarded it as far more organized than that on the other ground.

The actual benefit from the training session in general was nevertheless a quite controversial topic among players. Emmanuel kept himself away from the training matches in Feriköy and did independent exercises on the sideline. He stated that just playing the matches would never help him to improve his technical abilities, or even only keep the performance he was capable of when he was still playing in Nigeria. Simon, who came to İstanbul some months before, likewise admitted that training in Feriköy would not really help to keep up the best physical condition for possible trials at clubs:

'When you don't train under a coach, you just kick the ball, and it's not about kicking the ball, football is all about technicality. That's why it's 
good to play in the club. You can be maybe 80 or 90 percent fit, when you are not training with the club. But [in Feriköy] it's just to get familiar with the game. That is why you train three times in the week. But to tell you the truth, it's not enough.' 8

As becomes obvious from these statements, the training in Feriköy is not necessarily or in its own right seen by the players as an ideal possibility to keep up or improve one's physical condition or develop one's skills further. Therefore, a central aspect of nevertheless gathering on the pitch regularly, I argue, derives from the function of the football pitch as a valuable connection point, where players are able to share common experiences and knowledge and make contacts helpful for one's own career prospects.

This became visible in the course of Joshua's and Anthony's presence at the pitch; the two players had arrived in İstanbul together just a few days after me. After entering Turkey on a short-time business visa, they were both looking for a possibility to find a club where they could make a living as football professionals. Incidentally running into a former fellow player from Nigeria in the city, they were referred to the training pitch in Feriköy. Realizing the high number of unemployed African footballers in Turkey, all playing parttime on the training ground without great prospects for a paid career, they became disillusioned with their own chances of making it in Turkish football. Still, the connection with the friend they initially met provided for at least some opportunities for trial matches at different occasions. The friend, in his thirties himself, was a Nigerian national, who had been able to legalize his stay due to his marriage with a Turkish citizen, and had thus been able to sign up with some amateur clubs in İstanbul. Using his network, he tried to give his fellow players a chance to enter Turkish amateur football as well. Anthony was nevertheless quite sceptical about his chances of finding paid employment in football. Besides the regular training in Feriköy, he tried to establish some contacts within the Nigerian Christian community in İstanbul, looking for a chance to open an offshoot of his Pentecostal Church from which he had been trained as a pastor back in Nigeria.

The case of Anthony shows that for some of the ambitious football migrants there might be options apart from football worth pursuing within their larger migration project. Having played professional football in different African countries for a few years, he now realized that clinging on to his football career might no longer be possible in Turkey. In contrast to many players in Feriköy, who held on to their imagined career in football, even if they did not find an engagement for years, Anthony made sure to pursue

${ }^{8}$ Simon. Personal Interview. 15.09.2011. 
another option to secure his living in İstanbul. In order to open a Pentecostal church, he tried to use some of the contacts he made at the football pitch in Feriköy. Anthony knew how to make use of this connection point for his plans. Listening to the manifold problems of some players at the pitch, he proved his ability to give spiritual support and advice. He further accompanied other players to a Catholic church, where African migrants gather for Sunday service. This opened up even more possibilities of making contacts and finding followers for his church. For others, the training ground was a place to meet fellow football-playing migrants and keep their ambition in football alive.

To sum it up, for Anthony, but not only for him, the football pitch in Feriköy was a central meeting point for African football migrants in İstanbul. It was a place to practice their skills, spend some leisure time or keep up their dreams of a football career in Europe. Furthermore, it helped to deepen social relations among fellow football players. In some cases, the competition between the footballers for finding employment with clubs, lead to conflicts or even fights. Especially newcomers had a difficult time finding entry into the community of those who had been gathering on the training ground for months or years already. On the other hand the regular training session gave migrants the possibility to share everyday experiences of discrimination in Turkey or the difficulties of making a living day by day. Moreover, as some footballers came into the possession of legal residence permits, which enabled them to play in amateur clubs in İstanbul, the pitch became a place to share contacts to clubs and promote an entry into paid football for ambitious football players.

\section{Seeking a way to Europe}

Many of the players in Feriköy did not have coming to Turkey in mind specifically while they were looking for an opportunity to make it in professional football back in their home countries. They rather envisaged a way into a high-profiled European club side where they would find reputation as a footballer and realize their aspirations for a better social and financial status. Succeeding in this instance is, in most cases, not a question of skills alone. Instead, it is important to find helpful contacts within international networks of football professionals, officials and agents that are often named as 'transfer networks' (Poli, 2006:394). As accounts of players reveal, especially scouts and agents, whose activities seem often obscure and not very transparent to the footballers themselves, have taken over most of the placements of young African players in European clubs. In the case of the Nigerians and Ghanaians in İstanbul, those who were put in contact with a Turkish club by an agent or their manager accepted being sent to Turkey in hope of gaining prestige there and then getting transferred further to European clubs in order to advance their 
career. Some travelled to Turkey directly, having been invited for trials at professional clubs or their youth teams. Others had already travelled through several countries in Africa and at the fringes of the EU, sometimes employed as a footballer for a certain time period, still trying to get into Europe.

One of those was Simon, whom I met during one of my first visits to Feriköy. He told me that he had been to Armenia and Syria before he travelled on to Turkey where he had already been staying for about ten months at the time of my research. In his home country Nigeria, he had been playing in the Nigerian Premier League (NPL) for the teams of Nasawara United and Heartland for two seasons, before he continued his university education as an engineer. Struggling with the requests of his family to concentrate on his vocational career, he decided to continue his way in football and followed the call of a club in Ivory Coast where he got signed for half a season. Looking back on his time as a professional player in West African countries, he criticized the low wages and the lack of perspectives despite the efforts he had put into his career. In his opinion, corrupt managements in clubs, the NPL, and the national football association do not care much about the players. According to him, this unpleasant situation in professional football at home especially encourages the dreams of many young football players in Nigeria to try their luck with a career in Europe.

Having played half a season in Ivory Coast, Simon found an agent, who organized a trip for him and some fellow players to Armenia. Not knowing anything about the situation awaiting him there, in retrospect, Simon complained about the agent who had deliberately cheated on them. When they arrived at the club in Armenia, the team for the coming term, of which Simon was supposed to be a part of, had already been put together. As his family and friends in Nigeria had invested a lot to make his journey possible, returning home was out of the question:

'You put a lot of money in, because when people, yeah, you want to go and play football, you understand, they would like to encourage you, because they know there is money in football. When you break through tomorrow, you know, you have to come and pay them back, in one way or the other. So, I put a lot of money [into] this travel. So you don't expect me to go back without achieving what I came here for, you understand. ${ }^{9}$

Using his network of fellow football players, who live and play in different countries of the EU and its neighbours, he got in touch with a club in Syria. There, he was expected to show up for trials, but since his Armenian visa

${ }^{9}$ Simon. Personal Interview. 15.09.2011. 
- Ankara Üniversitesi SBF Dergisi • 68-1

had already expired, travelling there put him into trouble with the Armenian authorities. After he had finally made it to Latakia in Syria, he was confronted with the very same situation as in Armenia before. The Syrian club had already made up the team for the coming season. As Simon explained, a regulation of the Syrian football association only allows two professional foreigners in one team, and by the time he arrived, the club in Latakia had already signed two African players.

Not knowing, how to support himself in Syria and without any opportunity of finding employment as a footballer, Simon decided to travel on to Turkey with a short-term tourist visa. There, he found his way to Ankara and finally İstanbul; there he had the chance to connect to Nigerian countrymen and fellow football players. Having spent the last ten months in Turkey, Simon was still trying to find a way to promote his football career further. As he told me, he already had the chance to play trials at clubs but failed to be signed due to the lack of a residence permit. While for some time he had been doing some odd jobs to secure his survival, he now relied on money transfers from friends in order to save time and strength for training and regeneration. While he admitted that finding a club without 'papers' might not be possible, he was still convinced that this would be helpful in promoting his football career and that after playing in Turkey for some time, he would be able to recommend himself to other European clubs:

'I would like to play in one season in Turkey, you know, because it will be an advantage for me. If I play one season in Turkey it will boost my football profile, you know. If I happen to leave Turkey and go to another place, it won't be all that difficult for me, to play there, because they will know that I've really played one season here, so I've already started my professional career. That's why I'm still here. But if I want to go to another country without playing here, it will still be the same thing, you know, and I believe I have the chance of playing in Turkey, because there are so many clubs in Turkey. I just hope that one day I will get to the right club, you understand, that will give you guidelines on how to get the resident permit, so you can play. ${ }^{10}$

In summer 2011, his situation was giving Simon a hard time. He was realizing more and more that training in Feriköy was not opening up new chances to promote his ambitions in football any further. Trying to find alternative ways to enter Turkish professional football, he travelled to other Turkish cities several times in order to establish new contacts. But unlike some of the other players, who were eager to get in touch with young Turkish

${ }^{10}$ Simon. Personal Interview. 15.09.2011. 
football players who would then help them with contacts to clubs as well, Simon was skeptical about finding Turkish friends, due to the fact that he felt discriminated against as a black African in quite a number of situations and preferred to stay in the context of 'Blacks', as he put it. His migration biography shows one of the different paths that migration within the football economy takes. As he was already playing professional football in Nigeria and Ivory Coast, he expected that he would be able to successfully enter professional football abroad. But coming late to the possibly employing club due to a delay of his visa brought him into the situation of not really knowing how to find employment in football in foreign countries. In İstanbul, he is now coping with his new situation by holding on to his ambition through talks and during talks with donors back home and during training on the pitch.

\section{Hope and setbacks: A trial session}

Simon had nothing but his hope of escaping the difficult situation he found himself in. Without the necessary residence permit and far from a contract to a professional club in Turkey, he holds on to his football ambitions. In the meantime, Martins, whom I already mentioned in the introductory anecdote, had made contacts with one of the many semi-professional amateur clubs in İstanbul. After telling me about his positive impressions during a first training session with the team, he invited me to join him the next time he went to the club in the west of İstanbul. In the following, I will describe this meeting in order to show how the football migrants try to find their way in football, in spite of all setbacks. During the two hours bus drive across the city, Martins talked about his expectations connected to the newly established contact with the club. His manager, based in the United Kingdom, had held out the prospect of taking Martins to a club in England or Germany. Therefore he considered it necessary to first sign up with a club in Turkey, in order to be transferred on to a prospective club in Europe. His hope was that the club would support him in his application for a residence permit and work allowance, putting him in the position of finally being able to play regularly in a team, even if this was not one of the high-profiled professional İstanbul clubs.

The second amateur division club had mainly young talents in its team, and the players benignly welcomed Martins among them, already knowing him after a first trial session a few days ago. Often facing discrimination and mistrust from Turkish citizens in everyday situations in the city, on the football pitch Martins could convince the Turkish footballers with his skills and thereby earns their respect. But while he tried to show his abilities during the different technical exercises, he was often left out during the final training match. Lacking proficiency in language and other communication patterns of the team, 
it was visibly difficult for Martins to contribute to the performance of the side he was playing with. Commenting on the course of the trial session afterwards, he was convinced that he had been able to show some good examples of his skills. Being invited to another session encouraged him even more. The difficulties in communication continued even off the pitch. Although he had already been living in İstanbul for about 10 months at that time, he knew only a few Turkish words which were obviously not enough to speak with the coach after the training. As I observed while I was waiting for Martins to take the bus back to the city centre, the coach apparently tried to tell Martins how the process of trials and possible engagement for the upcoming season would continue. The other players of the team were all surrounding them, also talking insistently to Martins, which confused him even more. Calling a friend on the phone, who finally talked to one of the players, on our way back to the bus station, Martins told me that they expected him to come back two days later for the continuation of the trials. They further promised to organize a player's license, so that he would be able to play for them once the new season started.

Highlighting the opportunities of being hired by the club and later be transferred on to Germany or England which might now open new prospects for him, Martins was able to centre his talks and daily actions around the hoped-for employment. During the following training sessions in Feriköy in the mornings, he now often rested, arguing that he would have another trial session with his prospective new club in the evening. In conversations with fellow players and me, he stressed his expectation for the club to take care of the residence permit issues, allowing him to be signed up with them. Although the team was only playing in the second amateur division of the İstanbul region, he saw it as a (re-)entry ticket into a professional career that would finally also give him the chance to reach Europe, his hoped for final destination. I was not able to document in detail Martins' further efforts due to the end of my fieldwork stay in İstanbul, but later heard that his hope to get a residence permit and an engagement had failed. ${ }^{11}$

Martins' story is a multifarious example of many players' attempts to find ways to continue following their ambitions in football. Failing after his first entry to Turkey and in ongoing efforts to find paid employment in football is not restraining him from still trying again and again. As long as he believed in his own skills and abilities, he thought that another chance of making a step towards his purpose might still come up. Making it to Europe and the vision of

\footnotetext{
${ }^{11}$ While I began writing this article in July 2012 Martins was looking for a new chance related to the new visa and residency regulations.
} 
a professional football career are equal aims during the migration process and to reach one of them might sustain the other. Regarding his migration and life prospects, Martins was in an 'in-between' status, still holding on to his ambition in football but not or not yet able to make a living from it as he had expected when leaving his home country.

\section{Alternative ways: From football to business}

Simon and Martins, like many others footballers in their early or mid20 s, still have the will and the strength to pursue their ambitions in football. As they grow older, however, and at a certain point many of the players have to admit that the dream of becoming a football professional might indeed be outdreamt. Andrew was hit by this fact even earlier when he got injured during a training match several years before I met him in 2011 and was not able to continue playing football. Initially, he came to Turkey to improve his skills, as he regarded the conditions in professional football as better there than in his home country Nigeria. Entering one of the lower league clubs, however, he encountered similar difficulties as did Simon, Martins and other younger players I met. For Andrew, the injury was the crucial incident that made him realize that he had to find career alternatives to professional football. Having been engaged in several odd jobs for some years by then, he at one point got the chance to enter the small trade business that evolved in İstanbul during the early 2000s. The so-called 'suitcase trade' offered new possibilities to him: Starting with leading Nigerian traders of the important business places and shops, where they got their goods at, he soon administered commercial transaction and thus found a way for himself to enter the scene with his own small business. Using logistics of fellow Nigerian business people, he now trades clothes and other goods to Nigeria. While he got legal residence in Turkey a while ago, he now travels often to his home country and is looking forward to find a way to relocate his business there. In order to establish his own business, he was able to use many of the contacts that he made during his engagement in football. As he was trying to create more opportunities for himself and some fellow players and in order to attract Turkish clubs with the hope of them recognizing their skills and the prospective value for their teams, he started an 'African Cup' in 2004. Since then, he further promoted the tournament by finding sponsors for the different expenses, such as the renting fee for the pitch or the jerseys for the teams and also found recognition in Turkish and international media.

The ongoing professionalization of this small tournament led to the founding of the 'African Community Football Association', where Andrew now serves as secretary and continues to give young African football players the 
chance to play and show their skills to club officials and scouts. Not least due to his activities in the small football association, he made good contacts, especially within the Nigerian Community of İstanbul which has an elected committee which, however, appears inactive for most of the time. Nevertheless, the more contacts he made within different groups of Africans in İstanbul, the more opportunities he gained for him to further promote his own trading activities.

Staying in Turkey at a time when trade relationships to African countries intensified and especially small Turkish businesses opened up new chances for clever entrepreneurs, he took his chance and found a profitable alternative to his football ambitions. Building up his own business not only opened up the way for legal residence in Turkey but also provides him with the opportunity of returning to his home country as a successful business man. On the basis of many young players' argument that returning home without a success in football or in other ways during migration would have been shameful, Andrew had found a way to turn his stagnant football career into a quite successful business, for which he understood how to use the contacts and resources that originated from his former involvement with football.

\section{Conclusion}

The different stories of ambitious Nigerian football players reveal useful insights into an important part of African migrations to Europe and its neighbouring countries. The dream of playing professional football in Europe is very present among young men in many West African countries and the group of footballers I met during research in 2011 in İstanbul made use of one of the possible migration strategies, that of networks within global football. Their everyday practice of regular training, their efforts to make contacts which lead them to an employment with a club, and their rhetoric of an imagined career all indicate their ambitions to play football as a professional. The lives of the football migrants in İstanbul thus centred on these practices, and rhetoric give them a possibility to hold on to their dreams in regards to football: To one day play for a high-level European club and gain a reputation as a successful football professional is what keeps their ambitions alive. In using the term 'ambitious football migrants' in critique of the focus on successful players within the literature on African football migrants, I described some aspects of these everyday practices as well as the living conditions the migrants find themselves in. They understand how to use football as a starting point for their individual migration projects and, as some of the examples have shown, how to take up new strategies as they come along. Moreover, they often do so after realizing that the possibility to find employment as a professional footballer is 
no longer available. Still, as long as they continue to hope for a career in football, they engage in the rhetoric of an upcoming career in professional football to themselves and to others while continuing their regular training.

Therefore, I argue, it is necessary to move beyond categorizations like 'football migrant', 'transit migrant' and others in order to gain a better understanding of African migrations to Turkey. The categorization into ideal types not only provides a seemingly concrete rationale for restrictive state policies of migration but likewise limits our understanding of always complex migration practices and realities. Not least, the strength of ethnographic research and an anthropological approach to migration is to make the diverse living realities in African migrations visible and open up the view for its specific complexities. The stories of Simon, Martins, and the other football migrants portrayed in this article point to the importance in attending to the processual character of their migration projects, in which the answer to the question of whether their stories are stories of succeeding or failing as a professional football players can be answered only after a long periods of time . In the meantime their stories show that it is still possible for them to organize their current stay in İstanbul around the practices and rhetoric of an imagined career, as well as the ambition of establishing oneself as a professional football player. The new residency regulations mentioned in the introduction might now provide them with new possibilities of realizing the dream that fuels so many African migrants today, to succeed as a football player in Europe.

\section{Bibliography}

Alegi, Peter (2010), African soccerscapes: How a continent changed the world's game. (Athens: Ohio University Press)

Bale, John (2004), "Three Geographies of African Footballer Migration: Patterns, Problems and Postcoloniality", Gary Armstrong ve Richard Giulianotti (eds.), Football in Africa: Conflict, Conciliation, and Community (New York: Palgrave Macmillan): 229-46.

Brettell, Caroline ve James F. Hollifield (2008), "Introduction", Caroline Brettell and James F. Hollifield (eds.), Migration theory: Talking across disciplines, (New York: Routledge):130.

Brewer, Kelly T. ve Deniz Yükseker (2009), "A Survey on African Migrants and Asylum Seekers in İstanbul”, Ahmet İçduygu ve Kemal Kirişci(eds.), Land of diverse 
Migrations: Challenges of Emigration and Immigration in Turkey, (İstanbul: İstanbul Bilgi University Press):637-723.

Brewer, Kelly T., ve Deniz Yükseker (2011), "Astray and stranded at the gates of the European Union: African transit migrants in İstanbul", New Perspectives on Turkey, 44: 129-159.

Danis, Didem, Taraghi Cherie ve Jean-Francois Pérouse (2009), “"Integration in Limbo": Iraqi, Afghan, Maghrebi and Iranian Migrants in İstanbul", Ahmet İçduygu and Kemal Kirişci (eds.), Land of diverse Migrations: Challenges of Emigration and Immigration in Turkey, (İstanbul: İstanbul Bilgi University Press):443-636.

Darby, Paul (2010), "Out of Africa: The exodus of elite African football talent to Europe", Joseph Maguire and Mark Falcous (eds.), Sport and migration: Borders, boundaries and crossings, (London: Routledge):245-258.

Darby, Paul, Gerard Akindes ve Matthew Kirwin (2007), "Football Academies and the Migration of African Football Labor to Europe”, Journal of Sport \& Social Issues, 31 (2):143-161.

İçduygu, Ahmet and Kemal Kirişci (2009), Land of diverse Migrations: Challenges of Emigration and Immigration in Turkey (İstanbul: İstanbul Bilgi University Press)

Pannenborg, Arnold (2010), "Big Men, Big Gains? The Involvement of African Club Officials in the Transfer of Players", African Historical Review, 42 (1): 63-90.

Poli, Raffaele (2006), "Migrations and trade of African football players: historic, geographical and cultural aspects", Afrika Spectrum, 41 (3):393-414.

Poli, Raffaele (2008), "Explaining the "muscle drain" of African football players: world-system theory and beyond", Basler Afrika Bibliographien, BAB Working Paper (1)

Suter, Brigitte (2012), "Social Networks in Transit: Experiences of Nigerian Migrants in İstanbul", Journal of Immigrant \& Refugee Studies, 10 (2):204-222.

Today's Zaman (2012), "Interior Ministry relaxes residency, work permit rules for foreigners", 01.06.2012, http://www.todayszaman.com/news-282253-interior-ministry-relaxesresidency-work-permit-rules-for-foreigners.html ( 15.06.2012). 